\title{
Comparison of relapse rates and of mucosal abnormalities after healing of duodenal ulceration and after one year's maintenance with cimetidine or sucralfate: a light and electron microscopy study
}

\author{
F I TOVEY, E M HUSBAND, YIU CHU YIU, L BAKER, G McPHAIL, \\ M R LEWIN, A P JAYARAJ, AND C G CLARK*
}

From the Departments of Surgery and Pathology, Basingstoke District Hospital, Basingstoke and Departments of Surgery and Histopathology, Faculty of Clinical Sciences, University College London, London

SUMMARY Forty six patients with endoscopically diagnosed duodenal ulceration were randomly allocated to treatment with either sucralfate $1 \mathrm{~g}$ qds $(\mathrm{n}=24)$ or cimetidine $200 \mathrm{mg}$ tds and $400 \mathrm{mg}$ nocte $(\mathrm{n}=22)$. When the ulcers healed, a maintenance dose of sucralfate $1 \mathrm{~g}$ bd or cimetidine $400 \mathrm{mg}$ nocte was given for one year (or until relapse if earlier). Biopsies of duodenal mucosa adjacent to ulcer sites for light and electron microscopy were obtained before and after healing and again after one year's maintenance if the ulcer remained healed. Duodenal biopsies were also taken from 20 age and sex matched controls. Rates of healing and relapse during maintenance did not differ between the two treatments, although relapses occurred earlier with cimetidine. In the three year postmaintenance follow up period 10/13 cimetidine patients relapsed compared with four of 11 sucralfate patients $(p<0 \cdot 05)$, the relapses occurring significantly earlier in the cimetidine treated patients $(p<0 \cdot 05)$. Mucosal biopsies from both treatment groups still showed considerable abnormalities after healing. During maintenance, however, the sucralfate scores fell significantly $(p<0 \cdot 02)$ to near control levels unlike the cimetidine scores which remained raised at pretreatment values. The histological and ultrastructural changes were not predictive of later relapse. These findings favour the use of sucralfate in preference to cimetidine for maintenance treatment in the prevention of relapse of healed duodenal ulcers.

Ulcers healed with a short course of sucralfate have been reported to relapse later than those healed with cimetidine, although by one year recurrence rates are similar. ${ }^{1-3}$ Further, it has been reported that one year's maintenance with sucralfate gave a significantly lower recurrence rate than placebo. ${ }^{4}$ Maintenance treatment studies comparing sucralfate with cimetidine have also shown lower recurrence rates for the former drug although the differences did not achieve significance. $₫$

\footnotetext{
*We dedicate this paper to Professor Charles Clark who sadly died on 8 August 1988.

Address for correspondence: F I Tovey, Department of Surgery, Basingstoke District Hospital, Basingstoke, Hampshire.

Accepted for publication 3 October 1988
}

Light microscopy studies of duodenal mucosa adjacent to the ulcer site after healing with cimetidine have shown persistent abnormalities ${ }^{y-11}$ having been quantitatively measured by microdensitometry. ${ }^{12}$ Moshal and Gregory, ${ }^{1.314}$ using transmission electron microscopy, reported that duodenal mucosa adjacent to ulcers healed with tripotassium dicitrato bismuthate (De-Nol) showed less abnormalities than similar biopsies from patients treated with cimetidine. Subsequently, Gregory et al ${ }^{15-18}$ compared differences in the light and electron microscopic appearances of duodenal mucosa on ulcer healing between those treated by a single course of cimetidine and those treated with sucralfate, relating the changes to the duration of remission. They 
showed a correlation between the presence of gastric metaplasia and the length of remission, a greater degree of gastric metaplasia being present in the sucralfate patients with longer remission times.

The purpose of the present study was to compare the effect of long term maintenance treatment with sucralfate and cimetidine on the histological and ultrastructural changes in the duodenal mucosa adjacent to ulcer sites and to determine any possible relationship between these changes and the occurrence of relapse.

\section{Methods}

\section{PATIENTS}

A group of 46 patients between the ages of 18 and 75 , with endoscopically proven duodenal ulceration were randomly allocated to treatment with either sucralfate $1 \mathrm{~g}$ qds $(\mathrm{n}=24)$ or cimetidine $200 \mathrm{mg}$ tds and $400 \mathrm{mg}$ nocte $(\mathrm{n}=22)$. Endoscopy was repeated at six weeks and if the ulcer was unhealed, the full dose was continued for a further six week period when a further endoscopy was done. If the ulcer remained unhealed the code was broken and alternative treatment given. If the ulcer was healed at six or 12 weeks, then maintenance treatment was continued for one year, or until relapse if earlier, with either sucralfate $1 \mathrm{~g}$ bd or cimetidine $400 \mathrm{mg}$ hs. Endoscopy was repeated after one year or earlier if the patient had symptoms suggesting a relapse. If a relapse occurred alternative treatment or surgery was given. The patients remaining in remission at the end of one year's maintenance treatment have been followed up at three monthly intervals, the longest period so far being for 36 months.

\section{ABORATORY INVESTIGATIONS}

At the start of the trial, at the end of the healing phase of the study and after six and 12 months of maintenance therapy, a full blood count with prothrombin time was done together with the following biochemical investigations: urea, creatinine, electrolytes, calcium, phosphate, cholesterol and LFTs. Additionally, serum aluminium concentrations were measured by atomic absorption spectrophotometry at weeks $0,6,12,24$, and 48 .

\section{LIGHT AND ELECTRON MICROSCOPY}

At each endoscopy, two biopsies were taken close together from the mucosa adjacent to the ulcer site. One biopsy was sent for light microscopy and the other for electron microscopy. Endoscopists and histopathologists were independent and unaware of the treatment groups. For light microscopy, $4 \mu \mathrm{m}$ sections were stained for acid and neutral mucins with combined alcian blue and periodic acid Schiff
(PAS). The following features were noted: 1 Loss of villi; 2 Loss of goblet cells associated with alcian blue stained mucin; 3 The presence of PAS staining mucus in surface epithelial cells replacing absorptive cells; 4 The presence of erosions; 5 Inflammatory cell infiltration scored as follows: Acute inflammatory cells (predominantly polymorphs) - 3; Mixed acute and chronic inflammation (polymorphs, plasma cells, lymphocytes, eosinophils) - 2; Chronic inflammatory cells (plasma cells, lymphocytes, eosinophils) - 1; Normal - 0. A scoring system was devised for recording each of the five features listed above, each being allotted a score of three for the most severe microscopic appearance. This system thus had a possible maximum score of 15 . These changes are illustrated in Figures 1a and $b$ with their respective scores.

For electron microscopy, after processing of the specimens and orientation light microscopy, ultrathin sections $(60-90 \mathrm{~nm})$ were cut and mounted on copper grids and stained with uranyl acetate and Reynold's lead citrate. Sections were examined with a Jeol JEM 1200EX electron microscope. The size of the mounted specimens was too small to permit an assessment of the number of goblet cells and not deep enough for assessment of inflammatory cell infiltration. The staining technique also did not permit an assessment of the glycocalyx or glycocalyceal bodies. Attention was thus focused on changes in the surface mucus secreting and absorptive epithelial cells. Unlike light microscopy, there are numerous ultrastructural changes of varying significance such that a scoring system is both unwieldy and impractical. Instead, changes were recorded in grades of 0 to 5 , the grade of 5 indicating the maximum derangement seen. For ease of comparison with light microscopy, these 'grades' are referred to as scores hereinafter. The changes were graded as follows:

(1) Minor derangement of absorptive cells Dark granules near apex of cells

Scattered large vesicles

Sparse or clubbed microvilli

Widened intercellular spaces

Dilated endoplasmic reticulum

Large mitochondria .......................... 1

(2) Occasional mucus secreting cells, with normal cells in between

Clubbing of microvilli ........................ 2

(3) Intermediate mucus secreting cells containing moderate numbers of mucous vesicles (>2 above) ................................. 3

(4) Surface epithelial cells completely replaced by mucus secreting cells ............ 4

(5) As 4 above plus signs of disruption or cell death ....................................... 5 The best orientated sections were selected and 


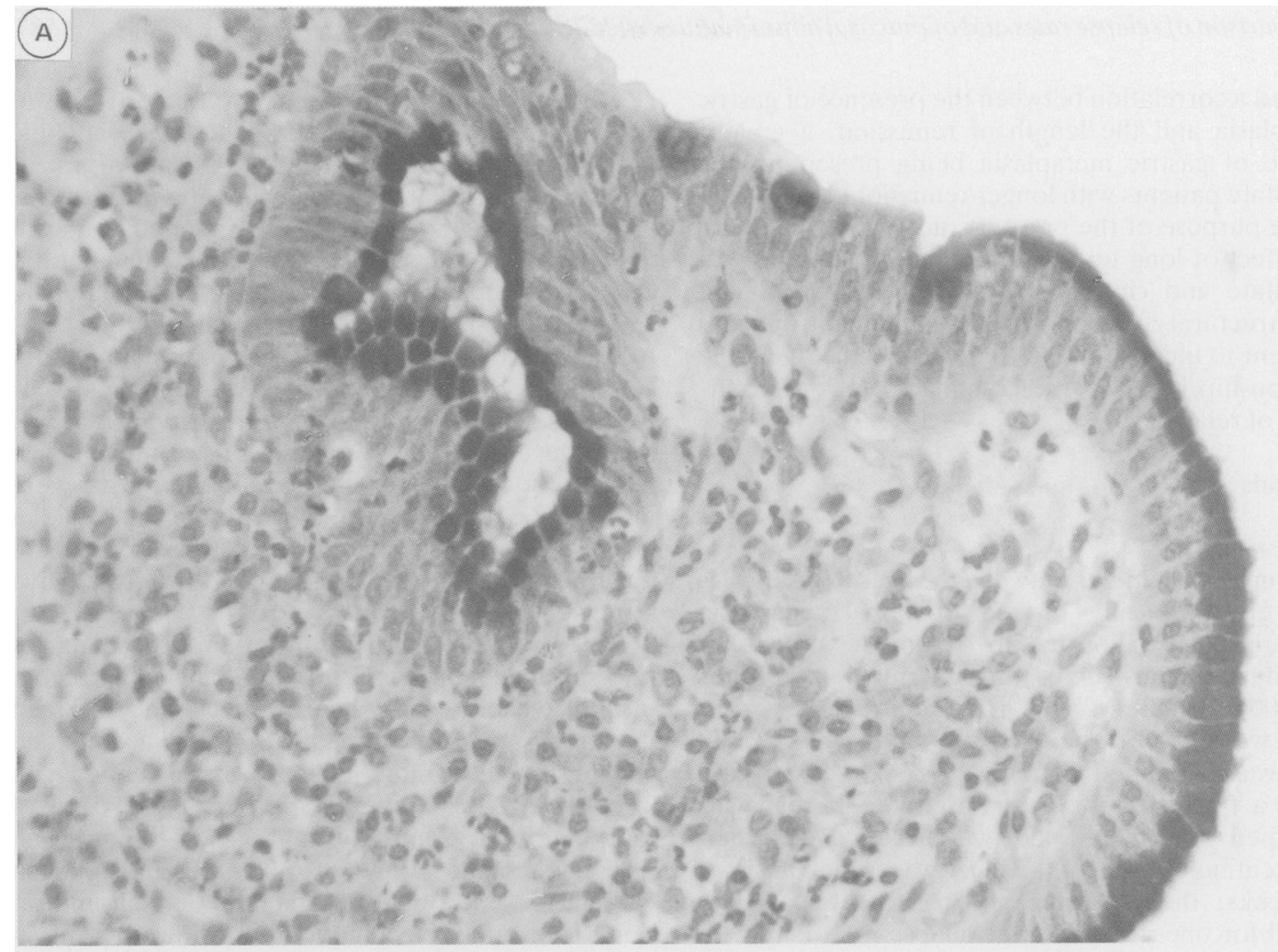

\section{B}

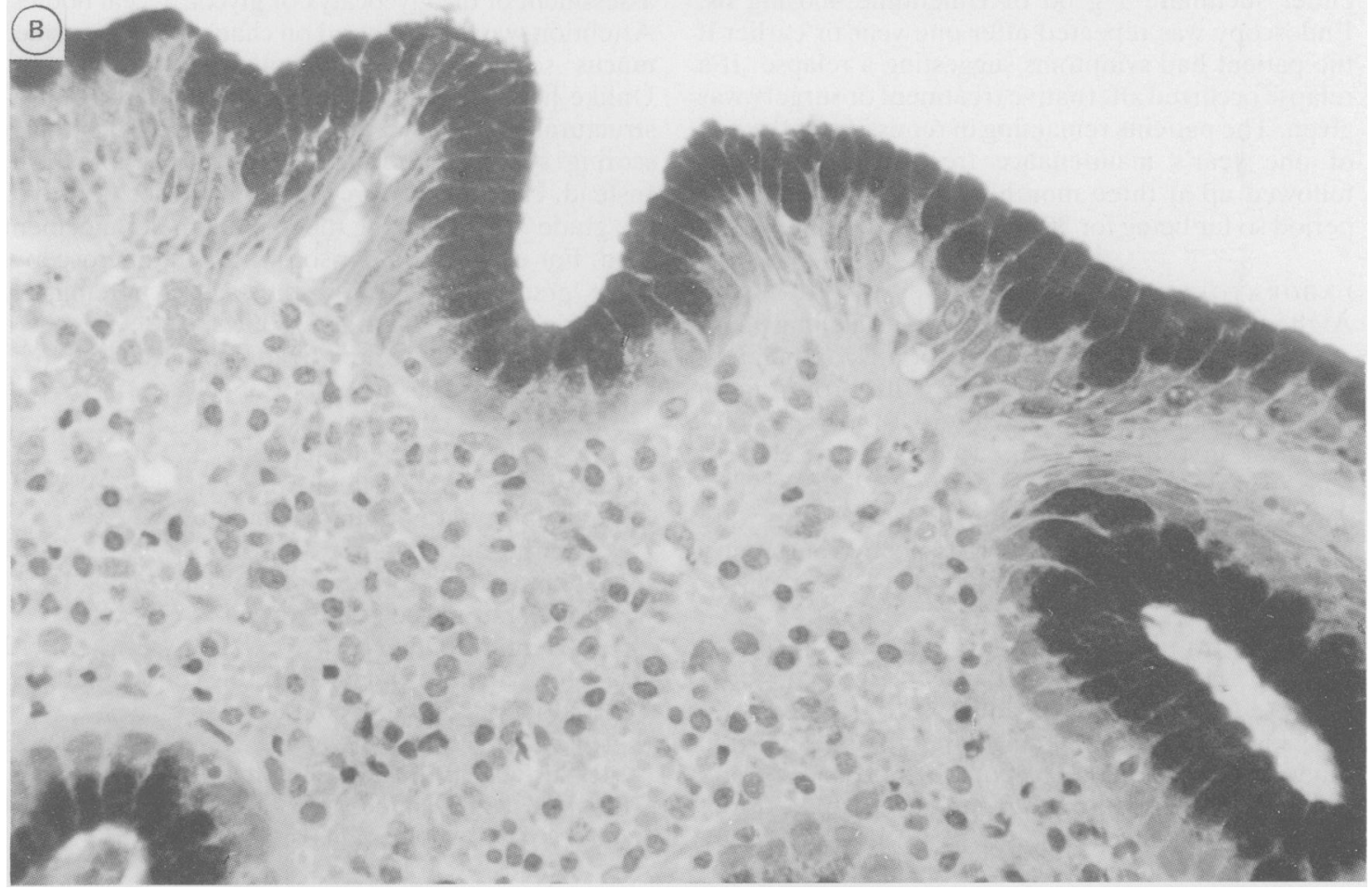

Fig. 1 (a) Light microscopy $(\times 600)$ showing patchy gastric metaplasia, Goblet cell loss $=2$, PAS staining =2, inflammatory cell infiltration $=2$, overall score $=6$. (b) Light microscopy $(\times 600)$ showing complete gastric metaplasia, Villous loss $=3$, goblet cell loss $=3, P A S$ staining $=3$, inflammatory cell infiltration $=1$, overall score $=10$. 


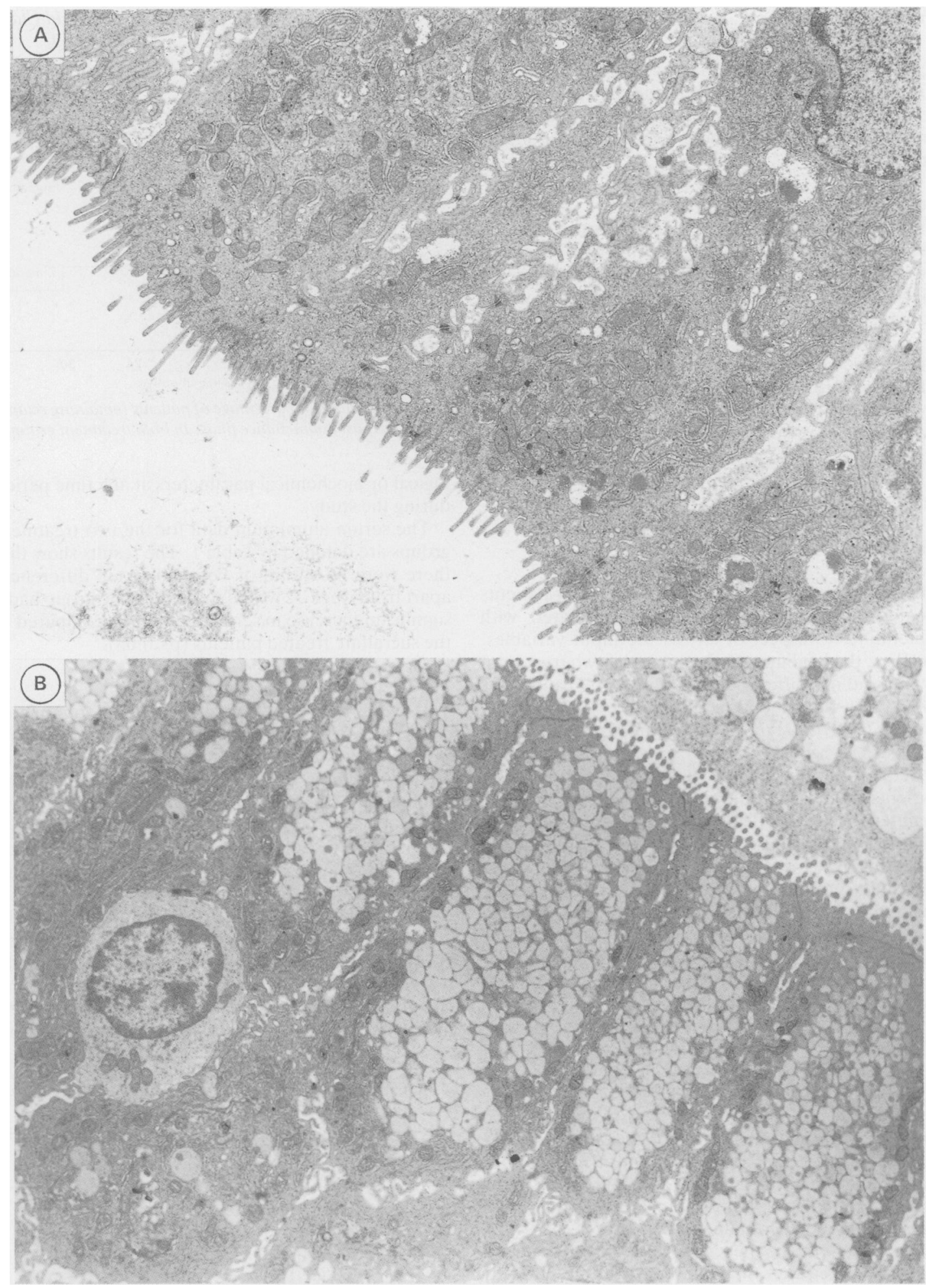

Fig. 2 (a) Electron microscopy $(\times 8000)$ showing near normal mucosa with some clubbing and loss of microvilli, grade $=1$. (b) Electron microscopy $(\times 5000)$ showing mucus secreting cells completely replacing absorptive epithelial cells, grade $=4$. 
several areas were scanned. Very little variation was found between different fields and an overall representative assessment was made. These appearances are shown in Figures $2 \mathrm{a}$ and $\mathrm{b}$ with the corresponding gradings.

\section{CONTROLS}

Two duodenal biopsies were taken from each of twenty, age and sex matched patients with non-ulcer dyspepsia and with endoscopically normal duodenal mucosa. The biopsies were processed as for the patients above to serve as controls.

STATISTICAL ANALYSIS

The data were expressed as medians and ranges or as frequencies. The results were statistically analysed by Wilcoxon's rank-sum test for paired or unpaired data where appropriate, by the $\chi^{2}$ or Fisher exact test where appropriate, by the log rank test of Peto et a $l^{19}$ and by the Spearman rank correlation method.

\section{Results}

There were no differences between the 24 patients treated with sucralfate and the 22 treated with cimetidine in respect of any of the input variables. Further, the healing rates between the two treatment groups did not differ, being $14 / 22(63 \cdot 6 \%)$ and $21 / 22$ $(95.5 \%)$ in the cimetidine group and $14 / 24(58.3 \%)$ and $21 / 24(87 \cdot 5 \%)$ in the sucralfate group at six and 12 weeks respectively.

Sixteen patients in the sucralfate group and 18 patients in the cimetidine group were entered into the maintenance phase. There were no differences in the numbers or rates of relapse between the two treatment groups with four of $18(22 \cdot 2 \%)$ relapses in the cimetidine group and four of $16(25 \%)$ relapses in the sucralfate group. Of the four relapses in the cimetidine group, two occurred at six months, one at nine months and one at 12 months whereas all four relapses in the sucralfate group (two symptomatic, two silent) were at 12 months.

At the end of the 12 month maintenance period, 13 patients in the cimetidine group and 11 of the sucralfate group were entered into the post-maintenance phase. The three year postmaintenance relapse rates are shown in Figure 3. There was a significantly greater incidence of postmaintenance, endoscopically confirmed symptomatic relapse in the cimetidine group with 10/13 (76.9\%) patients relapsing compared with four of 11 $(36.4 \%)$ in the sucralfate treated group $(\mathrm{p}<0.05)$. Further, relapse in the cimetidine group occurred significantly earlier than in the sucralfate treated group $(p<0.05)$. There were no within or between group differences in any of the measured haemato-

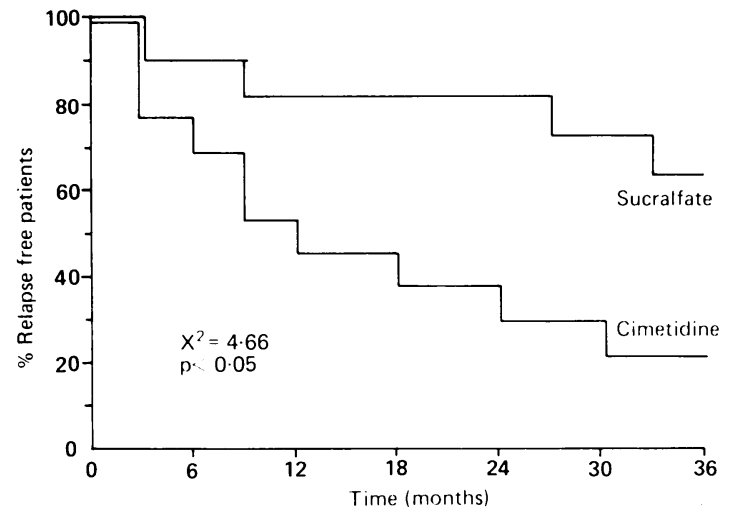

Fig. 3 Life table of percentage of patients remaining relapse free in the post maintenance phase in both treatment groups.

logical or biochemical parameters at any time period during the study.

The serum aluminium data for the two treatment groups are detailed in Table 1 . The results show that there were no within or between group differences apart from week 12 where the cimetidine group had a significant increase in serum aluminium compared to the sucralfate treated patients $(\mathrm{p}<0 \cdot 05)$.

\section{LIGHT AND ELECTRON MICROSCOPY}

The overall total scores for light and electron microscopy, before, after healing and after one year's maintenance treatment for the two groups are detailed in Table 2 . There were no differences in the total scores between the cimetidine and sucralfate groups by either microscopic method over any of the treatment phases. In order to study the 'within' treatment changes in histology over the initial, healed and maintenance periods of the study, only those patients with satisfactory biopsies for both light and electron microscopy over each of the three periods were selected so that paired analyses could be done. This provided 10 cimetidine and nine sucralfate treated patients whose results are detailed in Table 3. The scores on light microscopy were

Table 1 Median (range) serum aluminium concentrations* in the two study groups

\begin{tabular}{llll}
\hline $\begin{array}{l}\text { Time } \\
\text { (weeks) }\end{array}$ & $\begin{array}{l}\text { Cimetidine } \\
\text { group }\end{array}$ & $\begin{array}{l}\text { Sucralfate } \\
\text { group }\end{array}$ & $\begin{array}{l}\text { Cimetidine v } \\
\text { sucralfate }\end{array}$ \\
\hline 0 & $35(18-240)$ & $36(12-80)$ & NS \\
6 & $28(14-120)$ & $35(10-76)$ & NS \\
12 & $57(21-280)$ & $27(10-54)$ & $<0 \cdot 05$ \\
24 & $50(10-410)$ & $33(10-240)$ & NS \\
48 & $33(10-128)$ & $22(10-390)$ & NS \\
\hline
\end{tabular}

*Normal range for serum aluminium $0-172 \mu \mathrm{g} / \mathrm{l}$ ). 
Table 2 Median (range) total scores by light microscopy ( $L M)$ and electron microscopy (EM) in controls and in the initial, healing, and one year maintenance phases of the study

\begin{tabular}{|c|c|c|c|c|}
\hline $\begin{array}{l}\text { Treatment } \\
\text { phases }\end{array}$ & $\begin{array}{l}\text { Control } \\
\text { scores }\end{array}$ & $\begin{array}{l}\text { Cimetidine } \\
\text { scores }\end{array}$ & $\begin{array}{l}\text { Sucralfate } \\
\text { scores }\end{array}$ & $\begin{array}{l}\text { Cimetidine } \\
\mathrm{v} \\
\text { sucralfate }\end{array}$ \\
\hline Control LM & $1(0-4)$ & - & - & - \\
\hline Control EM & $1(0-3)$ & - & - & - \\
\hline Initial LM & - & $9(0-15)^{*}$ & $9(4-14)^{*}$ & NS \\
\hline Initial EM & - & $4(0-5)^{*}$ & $3(0-5)^{*}$ & NS \\
\hline Healed LM & - & $4(0-10)^{*}$ & $4(1-9)^{*}$ & NS \\
\hline Healed EM & - & $3(0-5)$ & $1(0-5)$ & NS \\
\hline Maintenance LM & - & $5\left((-12)^{*}\right.$ & $2(0-12)$ & NS \\
\hline Maintenance EM & - & $2(0-4)$ & $1(0-4)$ & NS \\
\hline
\end{tabular}

${ }^{*} \mathrm{p}<0 \cdot 01$. Compared with appropriate microscopic method in controls.

Table 3 Median (range) total scores by light microscopy (LM) and electron microscopy (EM) in the initial, healed, and maintenance phases in 10 cimetidine and nine sucralfate treated patients

\begin{tabular}{llll}
\hline \multirow{3}{*}{$\begin{array}{l}\text { Treatment } \\
\text { groups }\end{array}$} & \multicolumn{2}{l}{ Treatment phases } & \\
\cline { 2 - 4 } & Initial & Healed & Maintenance \\
\hline Cimetidine LM & $9(0-14)$ & $4 \cdot 5(0-8)^{*}$ & $6 \cdot 5(1-12)$ \\
Cimetidine EM & $3 \cdot 5(0-5)$ & $2 \cdot 5(0-5)$ & $2(0-4)$ \\
Sucralfate LM & $11(7-14)$ & $5(1-9)^{\dagger}$ & $2(0-12)^{*}$ \\
Sucralfate EM & $3(1-5)$ & $1(0-5)$ & $1(0-4)^{\dagger}$ \\
\hline
\end{tabular}

${ }^{*} \mathrm{p}<0 \cdot 01: \dagger \mathrm{p}<0 \cdot 02$. Compared with the appropriate microscopic method in the initial treatment phase. significantly reduced in the healed when compared to the initial phase for both treatment groups ( $\mathrm{p}$ values $<0 \cdot 02$ ). The scores for the maintenance phase in the cimetidine group however did not differ from the initial phase but in the sucralfate treated patients, the scores remained significantly lower $(p<0 \cdot 01)$. This showed that in the sucralfate treated patients, histological improvement of the duodenal mucosa persisted right through the maintenance phase of the treatment.

There were no differences in the electron microscopy scores between the three treatment phases in the cimetidine treated patients, although there was a trend for a fall in the score with healing. In the sucralfate group, whilst there were no differences between the initial and healed phases (although there was a reduction in the score), there was a significant improvement in the duodenal mucosa with a reduction in the score in the maintenance phase compared to the initial phase $(\mathrm{p}<0 \cdot 02)$.

The individual light microscopy scores together with the total scores for light and electron microscopy in both treatment groups over the whole study are detailed in Table 4. There were no differences in any of the individual light microscopy parameters either within or between the two treatment groups at any time throughout the study. Whilst some patients showed good correlation between light and electron microscopy scores, in others there was a wide variation such that overall there was no consistent relationship. The degree of gastric metaplasia was indicated by the combined light microscopy scores for villous loss, goblet cell loss and the presence of PAS staining mucus cells and corresponding electron

Table 4 Median (range) individual and total light microscopy scores and total electron microscopy scores in the two treatment groups over the total period of the study

\begin{tabular}{|c|c|c|c|c|c|c|c|}
\hline \multirow[b]{2}{*}{ Treatment } & \multicolumn{5}{|c|}{ Median (range) individual light microscopy scores } & \multirow{2}{*}{$\begin{array}{l}\text { - Total } \\
\text { LM scores }\end{array}$} & \multirow{2}{*}{$\begin{array}{l}\text { Total } \\
\text { EM scores }\end{array}$} \\
\hline & Loss of villi & Goblet cell loss & $P A S$ & Erosions & Inflamm. cells & & \\
\hline \multicolumn{8}{|l|}{ Cimetidine } \\
\hline Healing $6 / 52$ & $2(0-3)$ & $2(0-3)$ & $2(0-3)$ & $1(0-3)$ & $2(0-3)$ & $9(0-15)$ & $3(0-5)$ \\
\hline Healing $12 / 52$ & $2(2-3)$ & $2(2-3)$ & $2(2-3)$ & $2(0-3)$ & $2(2-3)$ & $11(3-14)$ & $3(2-5)$ \\
\hline Maintenance, no relapse & $1(0-3)$ & $2(0-3)$ & $1(0-3)$ & $0(0-1)$ & $1(0-2)$ & $3(0-9)$ & $3(0-5)$ \\
\hline Maintenance, relapse & $1(0-1)$ & $1(1-1)$ & $1(0-1)$ & $0(0-0)$ & $1(0-1)$ & $3(2-4)$ & $4(3-5)$ \\
\hline Post maintenance, no relapse & $1(0-3)$ & $1(0-3)$ & $2(0-2)$ & $0(0-1)$ & $1(1-3)$ & $5(1-12)$ & $2(1-4)$ \\
\hline Post maintenance, relapse & $1(0-3)$ & $1(0-3)$ & $1(0-3)$ & $0(0-1)$ & $1(0-3)$ & $5(0-11)$ & $2(()-4)$ \\
\hline \multicolumn{8}{|l|}{ Sucralfate } \\
\hline Healing $6 / 52$ & $2(0-3)$ & $2(1-3)$ & $2(0-3)$ & $0(0-3)$ & $2(1-3)$ & $9(4-14)$ & $3(1-5)$ \\
\hline Healing $12 / 52$ & $2(0-3)$ & $2(0-3)$ & $2(1-3)$ & $2(1-3)$ & $3(2-3)$ & $9(4-11)$ & $3(2-4)$ \\
\hline Maintenance, no relapse & $1(0-2$ & $2(0-2)$ & $1(0-3)$ & $0(0-1)$ & $1(0-3)$ & $4(0-9)$ & $2(0-5)$ \\
\hline Maintenance, relapse & $1(0-3)$ & $2(1-3)$ & $1(0-1)$ & $0(0-0)$ & $3(2-3)$ & $6(4-9)$ & $1(0-4)$ \\
\hline Post maintenance, relapse & $1(0-2)$ & $2(0-3)$ & $2(0-3)$ & $1(0-1)$ & $2(0-3)$ & $6(0-12)$ & $3(1-4)$ \\
\hline Controls & $0(0-1)$ & $0(0-1)$ & $1(0-1)$ & $0(0-1)$ & $0(0-1)$ & $1(0-4)$ & $1(0-3)$ \\
\hline
\end{tabular}


microscopy grades 3 and 4 . Light microscopy was of greater value in showing the extent of gastric metaplasia because of the larger microscopic fields examined. No correlation was found between the presence of gastric metaplasia and either healing time or relapse.

\section{Discussion}

The present study showed that the duodenal mucosa of patients treated for duodenal ulceration frequently did not return completely to normal at the time of ulcer healing or at the end of one years' maintenance. When maintenance treatment was discontinued, the cimetidine treated group had a significantly increased rate and frequency of relapse compared to the sucralfate treated patients. These differences would seem to be consistent with the differences in light and electron microscopy scores at the end of the one year's maintenance treatment, the sucralfate group showing lower scores than the cimetidine group. Later relapse during or after the period of maintenance therapy, however, bore no clear relationship to the histological or ultrastructural findings. The prognostic significance of these residual changes with regards to relapse or prolonged remission therefore remains uncertain. It needs to be remembered, however, that the relapses mostly occurred at some considerable time interval after the taking of the biopsy, during which time the appearances and mucosal scoring could have changed.

Gastric metaplasia has been regarded as a response to hyperacidity and may be related to resistance to ulceration. ${ }^{2022}$ Gregory, ${ }^{17} 1823-26$ (personal communication) whilst stating that a return to normal histology or ultrastructural morphology is the ideal accompaniment to ulcer healing, produced evidence that the presence of gastric metaplasia on healing represents a continuing defensive mechanism against hyperacidity and is associated with a higher remission rate than in those not showing this response. In our series, however, no correlation was found between gastric metaplasia and prolonged remission and our findings suggest that it is consistent with an unhealthy mucosa. This concept is supported by the finding that Campylobacter pylori infection in duodenal mucosa is found only in association with gastric metaplasia. ${ }^{27-30}$ It is also reported that prostaglandin $E_{2}$ generation is reduced in duodenal mucosa in the presence of gastric metaplasia (Dr S Pugh, personal communication).

It is regrettable that the association of Campylobacter pylori with relapse of duodenal ulceration was unknown when this study was designed and consequently the staining and culture of biopsies were not included in the protocol. It is known, however, that neither cimetidine nor sucralfate have any effect on Campylobacter pylori infection. ${ }^{31-33}$

A criticism of the present study is the poor correlation between the light and electron microscopy scorings in some patients. In this study the distance between the participating laboratories necessitated taking two individual biopsies close together. The degree of histological change, however, is known to vary from site to site in the duodenum, being greatest close to an ulcer site and least on the opposite wall. ${ }^{112}$ This could account for the poor correlation in some specimens because of an unavoidable distance between biopsy sites. In addition, the extremely small size of the electron microscopy sections compared with those for light microscopy could result in the former being sampled from a more normal or abnormal part of the biopsy specimen.

In conclusion, the findings reported here favour the use of sucralfate in preference to cimetidine for maintenance treatment in the prevention of relapse of healed duodenal ulcers. Its safety is confirmed by the absence of any increase in serum aluminium concentrations or other haematological or biochemical changes. The differences in relapse rate and improved morphological appearance may be related to an increase in prostaglandin generation in response to sucralfate. ${ }^{34-36}$

We would like to acknowledge the assistance of $\mathrm{Mr}$ A V Reynolds of Ayerst Laboratories Ltd and to thank the company for the supply of drugs and financial support. We should also like to thank Syntex Pharmaceuticals Ltd for their contribution to the costs of studying the control group.

\section{References}

1 Marks IN, Lucke W, Wright JP, et al. Ulcer healing and relapse after initial treatment with cimetidine or sucralfate. J Clin Gastroenterol 1981; 3 [suppl 2]: 163-5.

2 Marks IN, Wright JP, Lucke W, Girdwood AM. Relapse rates following initial ulcer healing with sucralfate and cimetidine. Scand J Gastroenterol 1983; 18 [suppl 83]: 53-6.

3 Lam SK, Hui WM, Lau WY, et al. Sucralfate overcomes adverse effect of cigarette smoking on duodenal ulcer healing and prolongs subsequent remission. Gastroenterology 1987; 92: 1193-201.

4 Behar J, Roufail W, Thomas E, Keller F, Dembach W, Tesler M. Efficacy of sucralfate in the prevention of recurrence of duodenal ulcer. Gastroenterology 1986; 90: 1343.

5 Bolin TD, Davis AE, Duncombe VM, Billington B. Role of maintenance sucralfate in prevention of duodenal ulcer recurrence. Am J Med 1987; 83 [suppl 3b]: 91-3. 
6 Libeskind M. Maintenance treatment of patients with healed peptic ulcer with sucralfate, placebo and cimetidine. Scand J Gastroenterol 1983; 18 [suppl 83]: 69-70.

7 Rodrigo M, Castillo P, Berengues J, et al. Sucralfato y cimetidina en la precencion de recidivas de la ulcera duodenal. Gastroenterol Hepatol 1986; 9: 267-71.

8 Rodrigo M, Berenguer J, Hinojosa J, Balanzo J, Segu J. Sucralfate and cimetidine as maintenance treatment in the prevention of duodenal ulcer recurrence. Am J Med 1987; 83 [suppl B]: 99-104.

9 Ottenjann R. Was Wunscht sich ein internist von einem ulkus therapeutikum. In: Blum AL, Hamma R, eds. Die behandlung des ulcus pepticum mit pirenzipin. Grafeling: Karl Demeter Verlag, 1978: 153.

10 Zangger J, Taufer M, Kratochil P, Bransbatter G, Auboch L. Morphology of the duodenal scar after treatment with pirenzipine and cimetidine. Dotevall G, ed. Proceedings of the VI World Congress of Gastroenterology. Stockholm: Excerpta Medica, 1982.

11 Van Deventer G, Schneidman D, Walsh J, Elashoff J, Weinstein W. Healed duodenal ulcers are histologically ill. Gastroenterology 1985; 88: 1390.

12 Morrissey SM, Ward PM, Jayaraj AP, Tovey FI, Clark CG. Histochemical changes in mucus in duodenal ulceration. Gut 1983; 24: 909-13.

13 Moshal MG, Gregory MA, Pillay C, Spitacls JM. Does the duodenal cell ever return to normal? A comparison between treatment with cimetidine and De Nol. Scand J Gastroenterol 1979; 14 [suppl 54]: 48-51.

14 Gregory MA, Moshal MG, Spitacls JM. The ultrastructural effect of tripotassium dicitrato bismuthate on the duodenal mucosa during ulceration. An ultrastructural study. S Afr Med J 1982; 62: 52-5.

15 Gregory MA, Moshal MG, Spitacls JM. Sucralfate versus cimetidine. A comparative study of mucosal morphology in duodenal ulcer healing. Scand J Gastroenterol 1982; 17 [suppl 78]: 101.

16 Gregory MA, Spitaels JM. Variations in the morphology of villous epithelial cells in the ulcerated duodenal mucosa. Proc Electron Microscopical Soc $S$ Afr 1982; 12: 57-8.

17 Gregory MA, Moshal MG, Spitacls JM. Changes in the morphology of villar epithelial cells adjacent to duodenal ulcers during the process of healing. Scand $J$ Gastroenterol 1982; 17: 441-8.

18 Gregory MA, Brouchaert CJ, Simjee AE. Morphologic analysis as a means of quantifying drug performance. Dig Dis Sci 1986; 31 [suppl]: 206.

19 Peto R, Pike MC, Armitage P, et al. Design and analysis of randomized clinical trials requiring prolonged observation of each patient. Br J Cancer 1977; 35: 1-39.

20 Rhodes J. Experimental production of gastric epithelium in the duodenum. Gut 1964; 5: 454-8.

21 James AH. Gastric epithelium in the duodenum. Gut
1965; 5: 285-94.

22 Patrick WJA. Denham D, Forrest APM. Mucous change in the human duodenum: a light and electron microscopic study and correlation with disease and gastric acid secretion. Gut 1974 ; 15: 767-76.

23 Gregory MA, Simjec AE. Prognostic classification of duodenal ulcers by means of endoscopic and morphologic analysis. Dig Dis Sci 1986; 31 [suppl]: 204.

24 Gregory MA. Quantification of ulcerative duodenal villous epithelial cell morphology. Dig Dis Sci 1986; 31 [suppl]: 450.

25 Gregory MA, Spitaels JM. Variations in the morphology of villous epithelial cells within $8 \mathrm{~mm}$ of untreated duodenal ulcers. J Pathol 1987; 153: 109-19.

26 Gregory MA, Spitacls JM, Simjec AE. The role of glycocalyceal bodies in duodenal ulcerogenesis. Dig Dis Sci 1986; 31 [suppl]: 177.

27 Steer HW. The gastro-duodenal epithelium in peptic ulceration. J Pathol 1985; 146: 355-62.

28 Steer HW. Surface morphology of the duodenal mucosa in duodenal ulceration. Gut 1984; 25 : 1203-10.

29 Phillips AD, Hine KR, Holmes GKJ, Woodings DF. Gastric spiral bacteria. Lancet 1984; ii: 100-1.

30 Thomas JM, Poynter D, Gooding C. et al. Gastric spiral bacteria. Lancet 1984; ii: 100.

31 Lambert JR, Hansky J, Davidson A, Pinkard K. Stockman K. Campylobacter like organisms (C.L.O.) in vivo and in vitro susceptibility to antimicrobial and antiulcer therapy. Gastroenterology 1985; 88: 1462.

32 Jones DM, Eldridge J, Whorwell PJ, Miller JP. The effect of various anti-ulcer regimens and antibiotics on the presence of Campylobacter pyloridis and its antibody. In: Pearson AD, Skirrow MB, Lior H, eds. Campylobacter III. Proceedings of the Third International Workshop on campylobacter infections. London: PHLS, 1985.

33 Langenberg M-L, Rauwo EAJ, Schipper MEI, et al. The pathogenic role of Campylobacter pyloridis studied by attempts to eliminate these organisms. In: Pearson AD, Skirrow MB, Lior H, eds. Campylobacter III. Proceedings of the Third International Workshop on campylobacter infections. London : PHLS, 1985.

34 Ligumsky M, Karmeli F, Rachmilewitz D. Sucralfate stimulation of gastric PGE 2 synthesis - possible mechanisms to explain its effective cytoprotective properties. Gastroenterology 1984; 86: 1164.

35 Hollander D, Tarnawski A, Krause W, Gergely H. Protective effect of sucralfate against alcohol induced gastric mucosal injury in the rat. (Macroscopic, histological ultrastructural and function time sequence analysis). Gastroenterology 1985; 88: 366-74.

36 Tarnawski A. Prevention and treatment of gastrointestinal mucosal injury with cytoprotective agents. Med J Aust 1985; 142 [suppl]: 513-7. 